\title{
Soft Skills, the B.Sc. Parallel for a Successful Engineer
}

\author{
Salameh S. Mahmoud \\ Curriculum and Instruction, King Abdul-Aziz University, Jeddah/KSA
}

\begin{abstract}
This study investigates the most common soft skills engineers should acquire in order to lead a successful career and the KPIs for each skill. The sample of the study is fifteen senior engineers from ten well-known companies in KSA. The data collection tool is interviewing the senior engineers in the sample about the required soft skills and the key performance indicators of each soft skill. The findings of the study showed that there are a number of soft skills that are necessary first to pass an interview and second to survive in your future career. Furthermore, the respondents in the interview agreed upon a group of KPIs (key performance indicators) engineers should have in order to reflect these soft skills. The study recommends that new engineer grads should go through a well -designed training course where they are exposed to authentic examples, videos, recoded materials and probably visits to engineering companies in order to acquire the most common soft skills.
\end{abstract}

Key words: KPI, soft skills, frequency of KPIs, senior engineers, new engineer grads

\section{INTRODUCTION}

The technical experience and the knowledge engineering students get from the academic institutions while getting their formal certificates starting from diplomas or bachelor degrees and ending with their higher certificates is called hard skills. These hard skills can be achieved by any student who joins a certain institution and manages to finish with varying percentages. On the other hand, soft skills are interpersonal qualities and personal attributes that one possesses through experience [11]. Today in the hard economic conditions, recruitment committees tend to have very strict rules where soft skills like integrity, flexibility and communication skills are highlighted. Employers believe that non-academic skills are linked to individual differences, and academic and occupational performance [10], [9]. They also think that Soft skills play very important role in differentiating engineers during employment and during career development and enable professionals to navigate smoothly and effectively through a wide variety of social and professional situations with a wide variety of people. What makes things challenging is that these skills are often not learned in a school and even at the university. There are no courses in the plans under the name "soft skills for undergraduates" that are formally taught for engineers or businessmen before they join the labor market. This research is done to trigger more interest in this very critical area that will certainly help fresh graduates get a better chance for getting better job opportunities.

\section{RESEARCH QUESTIONS}

What are the most important soft skills an engineer should have in order to lead a successful career?

What are the key performance indicators for each of the most common soft skills?

\section{REVIEW OF LITERATURE}

\section{The Importance of Soft Skills for Future Employability}

Soft skills are becoming of great importance to new grads especially engineers who are going to join the labor market. They are not just about communicating, but include ability to manage 
stress, to organize, and to provide solutions. The curriculum tends to ignore the fact that one day an engineer would be working in a team, reporting to someone, taking reports, dealing with work pressures, giving presentations, attending phone calls, sending mails ...etc. [1]. All the traits mentioned above are as important as technical skills engineers need to lead a successful career.

Recently employers start to get concerned about the apparent absence of soft skills competence among new graduates and suggest an assurance of a learning model for incorporating these skills into curricula [12]. This appears clearly in the percentage of people interviewed to those who pass interviews and manage to get jobs. [12] Emphasized the importance of soft skills for all students that need to develop their potential in different programs at the university. These skills are important for every person in an organization as they play a highly important role in the work place as well as in one's career success. They are applicable to every field of work and are typically hard to observe, quantify and measure. [9] Conducted a study to investigate the effect of a soft skills training program on the performance in group discussion of engineering students. The findings revealed the relation between soft skills training and performance in group discussion. They would also help students who are prospective employees to understand the importance of soft skills for their employability. Soft skills are not only needed for work, but they are also a life demand. Four key soft skills were highlighted by the Ministry of Education in Malaysia to enhance employability among university graduates [8]. [7] Held a comparison between hard skills and soft skills and supported by studies reached a conclusion that soft skills are more important. The impact of soft skills on people's success reached $90 \%$. He indicated that the main reasons for people's termination are based on their lack of soft skills especially attitude related issues.

\section{The Role of Academic Institutions and Training Centers}

The university preparation required for workplace communication was also compared to the feedback obtained from the organizations at the workplace through internal and external practices [3]; [5]. [13] Focused on the role of the stakeholders involved in preparing the engineering graduates in a technical college in Oman for employability. The immediate stakeholders are the students, the staff and the college administration which is mainly concerned for the KPIs identified. [2] Evaluated the methods for students to acquire soft skills during their higher education. The study also showed that universities focus on hard skills other than soft skills like creativity, problem solving, personal communication, writing and speaking skills. [4] Analyzed the role of soft skills for technical students in todays' global labor market and high- tech industry and highlighted the role of these skills in employment. The possibility of including soft skills in an English for specific purposes course in educational curricula of technological higher educational institutions has been emphasized. [6] investigated the state of education and, in particular, attitudes among educators, parents, and students towards the reading, writing and arithmetic on one hand and collaboration, communication, creativity, and critical thinking on the other hand. Globalization and technological change are transforming the needs of employers, who start to call for soft skills. The findings of the study showed that schools should pay more attention to preparing learners for the workforce.

\section{METHODOLOGY}

The aim of this study is to investigate the most common soft skills engineers should have and the key performance indicators for each of these soft skills. To achieve this a sample of fifteen senior engineers from a group of well-known companies in Jeddah/ KSA; in addition to 
university professors in the faculty of engineering were interviewed. Their opinions and suggestions were filtered into a final list to be used as a backbone for a training course. A list of suggested soft skills was used as a start for interviewing the members of the sample. The skills; in addition to a brief explanation for each skill are translated to Arabic for the engineers whose English language is a little poor. See appendix (1)

\section{RESULTS}

The interviewees responded to the questions using the prompts; they added to the soft skills used in the interview and they suggested KPIs that reflect those soft skills and make them less abstract. These soft kills and the KPIs can be developed into a very rich course for training fresh graduates from the faculty of engineering. The filtered soft skills and the KPIs are shown in table (1) below.

Table (1) shows the output of interviewing fifteen senior engineers in terms of the most common soft skills, the KPIs of each soft skill and the frequency of each KPI.

\begin{tabular}{|c|c|c|c|c|c|c|c|}
\hline $\begin{array}{l}\text { No. } \\
\#\end{array}$ & & Soft Skill & Freq. & $\begin{array}{l}\text { No. } \\
\#\end{array}$ & & Soft Skill & Freq \\
\hline \multirow[t]{11}{*}{1.} & & Communication Skills & & 10. & & Positive Attitude & \\
\hline & KPI: & & & & KPI: & & \\
\hline & 1 & $\begin{array}{l}\text { Listens with the intent to } \\
\text { understand }\end{array}$ & 5 & & 5 & Starts his day strong & 2 \\
\hline & 2 & Avoids interrupting people & 7 & & 2 & $\begin{array}{l}\text { Starts his day by listening to } \\
\text { something positive }\end{array}$ & 4 \\
\hline & 3 & $\begin{array}{l}\text { is aware of his/her body } \\
\text { language }\end{array}$ & 3 & & 3 & Stops negative thoughts & 3 \\
\hline & 4 & Makes eye contact & 6 & & 4 & Focuses on his strengths & 4 \\
\hline & 5 & $\begin{array}{l}\text { Does not speak quickly/ } \\
\text { slowly }\end{array}$ & 3 & & 5 & $\begin{array}{l}\text { Reveals his talents if he has } \\
\text { any. }\end{array}$ & 3 \\
\hline & 6 & $\begin{array}{l}\text { Does not send mixed } \\
\text { messages }\end{array}$ & 6 & & 6 & $\begin{array}{l}\text { Doesn't complain for any extra } \\
\text { little task }\end{array}$ & 5 \\
\hline & 7 & $\begin{array}{l}\text { is honest and sticks to } \\
\text { ethics }\end{array}$ & 5 & & 7 & $\begin{array}{l}\text { Doesn't get involved in } \\
\text { conspiracies against the } \\
\text { company or his boss. }\end{array}$ & 6 \\
\hline & 8 & $\begin{array}{l}\text { Be ready to talk in more } \\
\text { than one language }\end{array}$ & 5 & & 8 & $\begin{array}{l}\text { Informs about } \text { any } \\
\text { misbehavior or anything } \\
\text { against ethics. This is not } \\
\text { spying. }\end{array}$ & 4 \\
\hline & 9 & $\begin{array}{l}\text { Be aware of discourse } \\
\text { etiquette. }\end{array}$ & 3 & & 9 & $\begin{array}{l}\text { Mentors } \quad \text { inexperienced } \\
\text { engineers }\end{array}$ & 5 \\
\hline \multirow[t]{10}{*}{2.} & & Creativity & & 11. & & Team-work & \\
\hline & KPI: & & & & KPI: & & \\
\hline & 1 & $\begin{array}{l}\text { Tries to solve any problem, } \\
\text { even if it is not his }\end{array}$ & 1 & & 1 & Works with a team spirit & 3 \\
\hline & 2 & Overcomes fear of failure & 3 & & 2 & Doesn't behave selfishly & 7 \\
\hline & 3 & Uses brainstorming & 3 & & 3 & $\begin{array}{l}\text { Encourages others and deals } \\
\text { with them freely }\end{array}$ & 4 \\
\hline & 4 & $\begin{array}{l}\text { Avoids criticizing any } \\
\text { idea }\end{array}$ & 5 & & 4 & Shares ideas with his team & 5 \\
\hline & 5 & $\begin{array}{l}\text { Doesn't hesitate to ask } \\
\text { experienced people. }\end{array}$ & 4 & & 5 & $\begin{array}{l}\text { Is an active member in his } \\
\text { team }\end{array}$ & 8 \\
\hline & 6 & Pays attention to details & 3 & & 6 & $\begin{array}{l}\text { Isn't mean in giving advice or } \\
\text { consultation. }\end{array}$ & 5 \\
\hline & 7 & $\begin{array}{l}\text { Doesn't take things for } \\
\text { granted }\end{array}$ & 6 & & 7 & $\begin{array}{l}\text { Helps new engineers if he is } \\
\text { senior. }\end{array}$ & 7 \\
\hline & 8 & $\begin{array}{l}\text { Always attends } \\
\text { workshops, seminars or } \\
\text { lectures about creativity }\end{array}$ & 4 & & 8 & $\begin{array}{l}\text { Has positive attitude towards } \\
\text { teamwork }\end{array}$ & 5 \\
\hline
\end{tabular}




\begin{tabular}{|c|c|c|c|c|c|c|c|}
\hline 3. & & Adaptability & & 12. & & Work ethics & \\
\hline & KPI: & & & & KPI: & & \\
\hline & 1 & $\begin{array}{l}\begin{array}{l}\text { Equalizes between pros } \\
\text { and cons }\end{array} \\
\end{array}$ & 1 & & 1 & Focuses on his work & 4 \\
\hline & 2 & Attends early & 3 & & 2 & Makes work a priority & 2 \\
\hline & 3 & $\begin{array}{l}\text { Helps others to learn } \\
\text { something }\end{array}$ & 1 & & 3 & Takes work seriously & 2 \\
\hline & 4 & Attends training courses & 2 & & 4 & Avoids doing wrong things & 1 \\
\hline & 5 & Does good conduct & 3 & & 5 & $\begin{array}{l}\text { Knows his distractions and } \\
\text { minimizes them while } \\
\text { working }\end{array}$ & 1 \\
\hline & 6 & $\begin{array}{l}\text { Avoids controversy to } \\
\text { avoid problems }\end{array}$ & 2 & & 6 & Gets enough rest & 2 \\
\hline & 7 & $\begin{array}{l}\text { Doesn't complain for the } \\
\text { sake of complaining }\end{array}$ & 4 & & 7 & $\begin{array}{l}\text { Doesn't postpone todays work } \\
\text { until tomorrow }\end{array}$ & 3 \\
\hline & 8 & $\begin{array}{lll}\text { Adapts in new } \\
\text { environments }\end{array}$ & 5 & & 8 & $\begin{array}{l}\text { Doesn't get involved in any } \\
\text { planning against his company. }\end{array}$ & 3 \\
\hline 4. & & Flexibility & & 13. & & $\begin{array}{l}\text { Proficiency in computer } \\
\text { skills }\end{array}$ & \\
\hline & KPI: & & & & KPI: & & \\
\hline & 1 & $\begin{array}{l}\text { Does not get embarrassed } \\
\text { of his manager }\end{array}$ & 4 & & 1 & $\begin{array}{l}\text { Gets a course to boost his } \\
\text { computer skills }\end{array}$ & 7 \\
\hline & 2 & $\begin{array}{l}\text { Deals with changing } \\
\text { priorities }\end{array}$ & 3 & & 2 & Stands practice & 4 \\
\hline & 3 & Has the ability to change & 4 & & 3 & $\begin{array}{l}\text { Watches a video to boost his } \\
\text { computer skills }\end{array}$ & 3 \\
\hline & 4 & Works smartly & 1 & & 4 & Takes the ICDL license & 2 \\
\hline & 5 & $\begin{array}{l}\text { Listens to others' opinions } \\
\text { and changes his if he feels } \\
\text { he is wrong. }\end{array}$ & 7 & & 5 & $\begin{array}{l}\text { Practice using the computer in } \\
\text { all aspects of his job }\end{array}$ & 5 \\
\hline & 6 & $\begin{array}{l}\text { Doesn't } \\
\text { change }\end{array}$ & 6 & & 6 & $\begin{array}{l}\text { Keeps up with the most up to } \\
\text { date programs }\end{array}$ & 4 \\
\hline & 7 & $\begin{array}{l}\text { Accepts advice from the } \\
\text { experienced }\end{array}$ & 8 & & 7 & $\begin{array}{l}\text { Holds workshops in computer } \\
\text { skills for others in need }\end{array}$ & 5 \\
\hline & 8 & $\begin{array}{l}\text { Talks to people according } \\
\text { to their age and level of } \\
\text { education }\end{array}$ & 5 & & 8 & $\begin{array}{l}\text { Has presentation skills using } \\
\text { PowerPoint }\end{array}$ & 8 \\
\hline 5. & & Collaboration & & 14. & & Courtesy & \\
\hline & KPI: & & & & KPI: & & \\
\hline & 1 & $\begin{array}{l}\text { Helps others to learn } \\
\text { something }\end{array}$ & 4 & & 1 & $\begin{array}{l}\text { Remembers that Muslims are } \\
\text { brothers }\end{array}$ & 5 \\
\hline & 2 & Joins the group & 3 & & 2 & Makes eye contact & 6 \\
\hline & 3 & $\begin{array}{l}\text { Participates in voluntary } \\
\text { work }\end{array}$ & 3 & & 3 & $\begin{array}{l}\text { Starts a conversation by } \\
\text { asking questions about the } \\
\text { other person }\end{array}$ & 3 \\
\hline & 4 & $\begin{array}{l}\text { Be a mentor for fresh } \\
\text { engineers }\end{array}$ & 4 & & 4 & $\begin{array}{l}\text { Respects those older and more } \\
\text { experienced than him }\end{array}$ & 7 \\
\hline & 5 & Be an active team worker & 3 & & 5 & Doesn't underestimate others & 4 \\
\hline & 6 & $\begin{array}{l}\text { Never complains when } \\
\text { extra work is sometimes } \\
\text { required }\end{array}$ & 5 & & 6 & $\begin{array}{l}\text { Takes true Muslims as his } \\
\text { models }\end{array}$ & 3 \\
\hline & 7 & $\begin{array}{l}\text { Participates in social } \\
\text { activities and events }\end{array}$ & 3 & & 7 & $\begin{array}{l}\text { Isn't arrogant even if he is the } \\
\text { most qualified. }\end{array}$ & 4 \\
\hline & & & & & 8 & $\begin{array}{l}\text { Is tolerant of mistakes if he is } \\
\text { holding a managerial post. }\end{array}$ & 3 \\
\hline 6. & & Leadership & & 15. & & Dedication & \\
\hline & KPI: & & & & KPI: & & \\
\hline & 1 & Is passionate & 1 & & 1 & attends early & 4 \\
\hline & 2 & Improves communication & 2 & & 2 & Does his work well & 4 \\
\hline
\end{tabular}




\begin{tabular}{|c|c|c|c|c|c|c|c|}
\hline & & skills & & & & & \\
\hline & 3 & $\begin{array}{l}\text { Continues to educate and } \\
\text { mentor }\end{array}$ & 1 & & 3 & Works with ethics & 4 \\
\hline & 4 & develops himself & 2 & & 4 & Gives more time to his work & 5 \\
\hline & 5 & $\begin{array}{lll}\begin{array}{l}\text { Motivate } \\
\text { greatness }\end{array} & \text { others } & \text { to } \\
\end{array}$ & 2 & & 5 & Gives more effort to his work & 6 \\
\hline & 6 & $\begin{array}{l}\text { Disciplined in his } \\
\text { professional (and personal) } \\
\text { life }\end{array}$ & 1 & & 6 & Is committed to his work & 4 \\
\hline & 7 & Shows enthusiasm & 1 & & 7 & Gives volunteering solutions & 3 \\
\hline & 8 & Is confident & 2 & & 8 & Assists co- workers & 3 \\
\hline & 9 & Listens Effectively & 2 & & 9 & Does not show indifference & 5 \\
\hline 7. & & Self-confidence & & 16. & & Punctuality & \\
\hline & KPI: & & & & KPI: & & \\
\hline & 1 & Trains himself & 2 & & 1 & Uses a timer & 4 \\
\hline & 2 & $\begin{array}{l}\text { Finds people who boost his } \\
\text { confidence }\end{array}$ & 4 & & 2 & $\begin{array}{l}\text { Everything will be ready the } \\
\text { night before }\end{array}$ & 2 \\
\hline & 3 & $\begin{array}{l}\text { People with confidence } \\
\text { tends to smile more }\end{array}$ & 3 & & 3 & $\begin{array}{l}\text { Keeps his essentials near the } \\
\text { door }\end{array}$ & 1 \\
\hline & 4 & $\begin{array}{l}\text { Not affected negatively by } \\
\text { negative comments }\end{array}$ & 2 & & 4 & $\begin{array}{l}\text { Forwards his watch five } \\
\text { minutes }\end{array}$ & 4 \\
\hline & 5 & stops his inner critic & 2 & & 5 & Always arrives in time & 10 \\
\hline & 6 & $\begin{array}{l}\text { Never says no, but I will } \\
\text { try }\end{array}$ & 3 & & 6 & Apologizes for late arrival & 4 \\
\hline & 7 & $\begin{array}{l}\text { uses ice breakers while } \\
\text { talking to others }\end{array}$ & 4 & & 7 & $\begin{array}{l}\text { The concept of time means } \\
\text { much to him }\end{array}$ & 6 \\
\hline 8. & & Honesty & & 17. & & $\begin{array}{l}\text { Problem solving and critical } \\
\text { thinking }\end{array}$ & \\
\hline & KPI: & & & & KPI: & & \\
\hline & 1 & Has faith in god & 4 & & 1 & $\begin{array}{l}\text { Frames problems using a } \\
\text { systematic, repeatable process. }\end{array}$ & 5 \\
\hline & 2 & $\begin{array}{l}\text { Raises awareness of the } \\
\text { importance of honesty }\end{array}$ & 2 & & 2 & Develops and tests solutions. & 5 \\
\hline & 3 & $\begin{array}{l}\text { Isn't involved in any } \\
\text { plotting against his } \\
\text { company }\end{array}$ & 3 & & 3 & $\begin{array}{l}\text { Identifies user needs and } \\
\text { develops solutions to meet } \\
\text { them }\end{array}$ & 6 \\
\hline & 4 & $\begin{array}{l}\text { Doesn't reveal secrets } \\
\text { about his company. }\end{array}$ & 8 & & 4 & $\begin{array}{l}\text { Uses design thinking to } \\
\text { generate ideas and discover } \\
\text { creative solutions. }\end{array}$ & 4 \\
\hline & 5 & $\begin{array}{l}\text { Doesn't spy his colleagues } \\
\text { to the boss }\end{array}$ & 7 & & 5 & Plans and executes research & 3 \\
\hline & 6 & $\begin{array}{l}\text { Doesn't tell lies to please } \\
\text { or revenge of others in his } \\
\text { company }\end{array}$ & 6 & & 6 & $\begin{array}{l}\text { Designs and builds effective } \\
\text { surveys }\end{array}$ & 4 \\
\hline & 7 & $\begin{array}{l}\text { Doesn't say bad things } \\
\text { about his former company } \\
\text { or boss }\end{array}$ & 9 & & 7 & $\begin{array}{l}\text { Thinks positively and } \\
\text { participates in team work to } \\
\text { solve problems }\end{array}$ & 6 \\
\hline & 8 & $\begin{array}{l}\text { Has positive attitudes } \\
\text { towards his work and } \\
\text { colleagues }\end{array}$ & 8 & & 8 & $\begin{array}{l}\text { Helps others in solving their } \\
\text { problems }\end{array}$ & 5 \\
\hline 9. & & Self-motivation & & & & & \\
\hline & KPI: & & & & & & \\
\hline & 1 & Maintains positive attitude & 2 & & & & \\
\hline & 2 & helps others & 2 & & & & \\
\hline & 3 & $\begin{array}{l}\text { Communicates and talks } \\
\text { for motivation }\end{array}$ & 2 & & & & \\
\hline & 4 & Discovers his interest & 4 & & & & \\
\hline
\end{tabular}




\begin{tabular}{|l|l|l|l|l|l|l|l|}
\hline & 5 & $\begin{array}{l}\text { Doesn't give up when he } \\
\text { faces problems }\end{array}$ & 4 & & & & \\
\hline & 6 & $\begin{array}{l}\text { Learns from his and others' } \\
\text { mistakes. }\end{array}$ & 5 & & & & \\
\hline & 7 & $\begin{array}{l}\text { Attends workshops and } \\
\text { seminars about motivation. }\end{array}$ & 4 & & & & \\
\hline & 8 & $\begin{array}{l}\text { Not easily frustrated by } \\
\text { other }\end{array}$ & 5 & & & & \\
\hline
\end{tabular}

As shown in table (1) there are seventeen soft skills that are filtered among others resulted from the interview with fifteen senior engineers. In addition, there are nearly eight KPIs for each skill and the frequency of each skill.

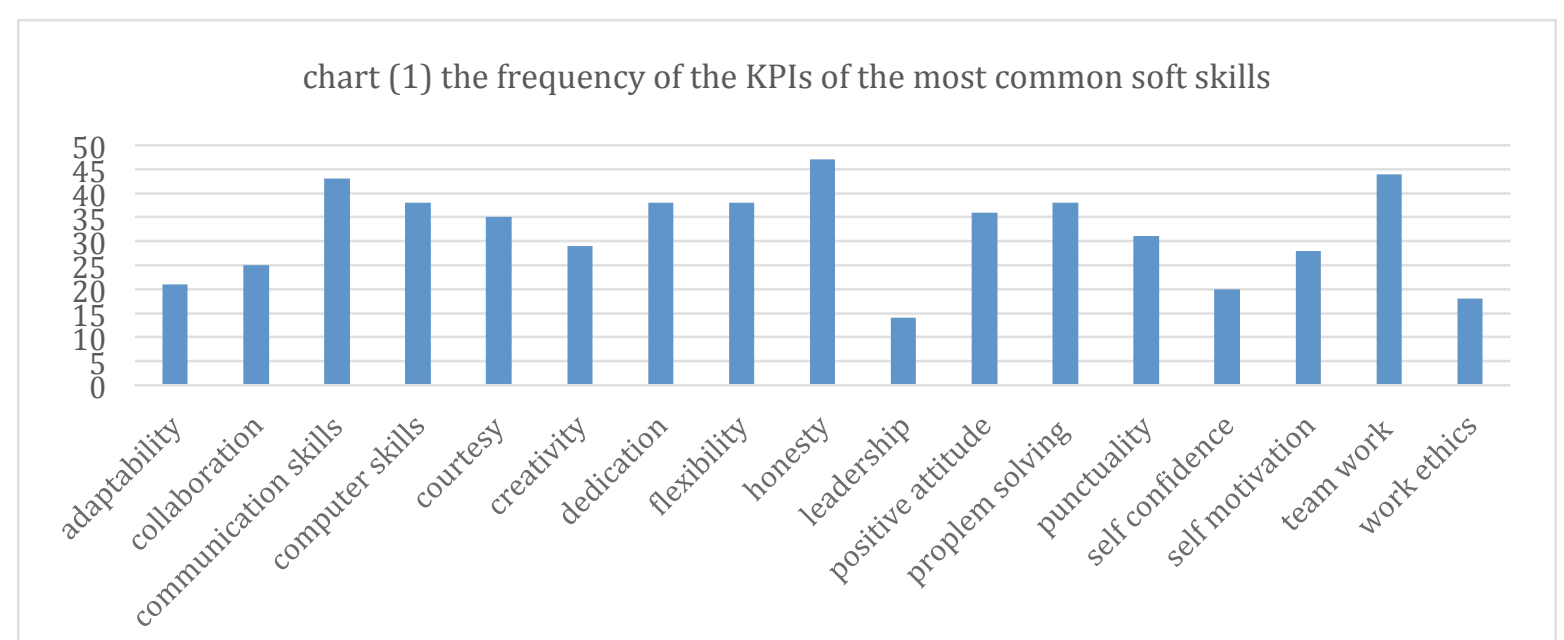

Chart (1) shows the frequency of the key performance indicators of the most common soft skills resulted from the interview with the fifteen engineers. The $X$ axis represents the seventeen soft skills and the $Y$ represents the total frequency of the KPIs for each soft skill.

\section{DISCUSSION}

The research problem is that newly graduated engineers in general and new graduates from the faculty of engineering at King Abdulaziz University in particular don't have enough soft skills that enable them to stand out in job interviews and consequently have employability chances to have a successful future career. The two questions of this study are about the most important soft skills engineers should have and the key performance indicators for each skill. The data collection tool was an interview with fifteen experienced engineers from different fields who are usually part of the recruitment committees in their companies. The result of the interview was a group of seventeen soft skills and nearly eight KPIs for each of them. These soft skills are considered important because they came from the field and from experienced engineers who are usually involved in job interviews.

The importance of the soft skills has been emphasized by other studies which considered them at least as important as hard skills, [[11]; [8]; and [4]]. [6] Found out that a comparison between shareholders' attitudes towards soft skills and hard skills was in favor of soft skills. Most of the researches cited in this study share the recommendation that soft skills should be included in curricula of schools, colleges and universities, [[12];[5]; [13]; and [2]].

A quick look at chart (1) above shows that honesty, teamwork, communication skills and computer skills were the most frequent. This shows that these skills are the most important and the most emphasized during interviews and consequently the most required in the work 
place. In the researchers point of view this seems logical because these skills especially communication skills and computer skills are very important to gain new information and skills from other more experienced engineers and the web of knowledge. The second important group is dedication, flexibility, positive attitude and problem solving. This also seems logical especially for dedication and positive attitude as most of the engineers in KSA are nor Saudis and these two qualities are necessary as they reflect interest in the success of companies and perfect performance of work. The rest of the skills, though not as important as the first two groups, still gain importance because they are mentioned by experienced engineers.

The interview with experienced engineers was meant to know which skills employers consider important when hiring new engineering graduates, the priority of these skills and which skills are missing. After classifying all skills based on the frequency of the KPIs, it becomes urgent that engineering education institutions should: try to improve the skill set of graduates, recognize the importance of Soft Skills, and use different ways of assessment and teachinglearning processes. They should also steer curricula away from lower-order thinking skills, such as remembering and understanding, toward higher-order skills, such as analyzing and solving engineering problems, as well as creativity; and most importantly interact more with employers to understand the real demands for the labor market. With regard to the teachinglearning processes, the engineering academic institutions should design training programs to respond to major skills' gaps, using learning styles based methodologies that echo the highorder thinking skills. For example, enhancing teamwork skills using active and visual learning strategies, and problem solving skills using task- based learning strategies. In other words, the soft skills may not be taught like a separate course called "Soft Skills for Engineers"; they are better given to students as doses as teaching strategies while instructing other courses.

\section{RECOMMENDATIONS}

Teachers need a high diploma after their bachelor degree before they go to the classroom where they get training on how to deal with students and parents and how to tackle critical situations throughout their career. Similarly engineers and business students should go through training on how to deal with the people around them through exposure to soft skills being practiced in the workplace. These soft skills help them do their jobs and allow them to effectively and efficiently use their technical skills and knowledge. They improve the way they interact with their bosses, co-workers and customers. They also permit them to get their work done on time and they influence how these employees feel about their jobs and how others perceive them.

An important thing to note is that soft skills are transferable between occupations. While you may have to go back to school to learn new technical skills if you change careers, you can always take your soft skills with you since they are valued in a variety of fields. That's why employers expect you to have certain character traits. In any job announcement you find such preferences by employers like excellent communication skills, strong organizational skills, team player, and strong listening ability.

The facts about the importance of soft skills throughout this research call for an instant action to consider equipping graduates from the faculty of engineering and other fields with the soft skills necessary for passing interviews first, then leading a successful future career. This can be achieved through field training while and post their university studies. 


\section{ACKNOWLEDGMENT}

I would like to thank Mr. Osamah Al-Amoudy-one of my students in IE200 course) for helping be in the interview. I would like also to thank the interviewees- the senior engineers- for their help and cooperation. Special thanks go to my wife, my two daughters and my three sons for their patience and staying at home while I was busy doing my research.

\section{References}

Aly, Majdy (2014) Top 5 Must-Have Soft Skills for Professional Engineers. https://www.linkedin.com/.../20140623195942-133431655-top-5-m, Retrieved, 28thNov. 2016

Arat, Melih (2014) Acquiring Soft Skills at University. Journal of Education and Industrial Studies in the World, August 2014, Volume: 4 Issue: 3 Article: 09 ISSN: 2146-7463

Beard, D., Schwieger, D., \& Surendran, K. (2007). Incorporating soft skills into accounting and MIS curricula. In Proceedings of the 2007 ACM SIGMIS CPR conference on 2007 computer personnel doctoral consortium and research conference: The global information technology workforce (pp. 179-185), St. Louis, MO: ACM

Drozdovych, N. Yu. (2016) Enhancing Students' Soft Skills Through English for Specific Purposes. Journal of the National Technical University of Ukraine "KPI": Philology and Educational Studies. Vol 7pp: 26-30

Fattacharyya, Ena and et al (2009) Internship Students' Workplace Communication Skills: Workplace Practices and University Preparation. Conference for Industry and Education Collaboration American Society for Engineering Education February 4-6, 2009, Orlando, Florida

Greenberg, A. D. \& Nilson, A. H. (2015) The Role of Education in Building Soft Skills Copyright (C) 2014, 2015 Wainhouse Research,

Hawkins, mike (2014) Hard Skills Versus Soft Skills - Which Are Most Important. Albine Link Corporation. w ww.alpinelink.com. Visited Nov. 18th, 2016

khalid, N. and et al (2014) Importance of Soft Skills for Industrial Training Program

Employers' Perspective. Asian Journal of Social Sciences \& Humanities Vol. 3(4), pp: 10-18

November, ISSN: 2186-8492, ISSN: 2186-8484 Print www.ajssh.leena-luna.co.jp

Nayak, Gopa. (2014) The Effect of a Soft Skills Training Program on the Group Discussion Skills of Engineering Students. IUP Journal of Soft Skills. Vol. 8, No. 3, pp:

Premuzic, T., Arteche, A. and Bremner, A. J. ( 2010) Soft skills in higher education: importance and improvement ratings as a function of individual differences and academic performance. Educational Psychology Vol. 30, No. 2, PP: 221-241

Robles, M. M. (2012) Executive Perceptions of the Top 10 Soft Skills Needed in Today's Workplace. Business Communication Quarterly 75(4) $453-465$

Sejzi, A. A. et al (2013) Important Soft Skills for University Students in 21th Century. Conference: 4th International Graduate Conference on Engineering, Science, and Humanities (IGCESH 2013), At Universiti Teknologi Malaysia (UTM), Johor, Malaysia, Volume: vol. 1, PP 1088-1093

Sivaraman, H. et al (2013) Key Performance Indicators of Employability of Graduating Engineers from an Engineering College in Oman. International Journal of Multidisciplinary Sciences And Engineering, VOL. 4, NO. 9, October. Vol. 4, No. 9 pp: 34-39 
APPENDIXES

Appendix (1) The form the researcher used while interviewing respondents

\begin{tabular}{|c|c|c|c|c|c|}
\hline $\begin{array}{l}\text { No. } \\
\#\end{array}$ & & Soft Skill & $\begin{array}{l}\text { No. } \\
\#\end{array}$ & & Soft Skill \\
\hline \multirow[t]{3}{*}{1.} & & Communication Skills & 10. & & Positive Attitude \\
\hline & Definition: & $\begin{array}{l}\text { Delivering compelling } \\
\text { content. Speaking, writing, } \\
\text { and listening in a } \\
\text { manner that captures } \\
\text { people's attention and } \\
\text { motivates them to take } \\
\text { action. Showing empathy. } \\
\text { Making others feel } \\
\text { heard and valued. (Hawkin, } \\
\text { 2014) }\end{array}$ & & Definition: & $\begin{array}{l}\text { Having a positive can-do } \\
\text { attitude. Showing gratitude. } \\
\text { Focusing on what can be done } \\
\text { better in the future rather than } \\
\text { dwelling on what wasn't done } \\
\text { well in the past. Being humble. } \\
\text { (Hawkin, 2014) }\end{array}$ \\
\hline & KPI: & & & KPI: & \\
\hline \multirow[t]{3}{*}{2.} & & Creativity & 11. & & Team-work \\
\hline & Definition: & $\begin{array}{l}\text { Creativity is the act of } \\
\text { turning new and imaginative } \\
\text { ideas into reality. Creativity } \\
\text { is characterized by the } \\
\text { ability to perceive the world } \\
\text { in new ways, to find hidden } \\
\text { patterns, to make } \\
\text { connections between } \\
\text { seemingly unrelated } \\
\text { phenomena, and to generate } \\
\text { solutions. Creativity } \\
\text { involves two processes: } \\
\text { thinking, then producing. If } \\
\text { you have ideas but don't act } \\
\text { on them, you are } \\
\text { imaginative but not creative. } \\
\text { www.merriam- } \\
\text { webster.com/dictionary }\end{array}$ & & Definition: & $\begin{array}{l}\text { Teamwork means that people } \\
\text { will try to cooperate, using their } \\
\text { individual skills and providing } \\
\text { constructive feedback, despite } \\
\text { any personal conflict between } \\
\text { individuals. } \\
\text { www.merriam- } \\
\text { webster.com/dictionary }\end{array}$ \\
\hline & KPI: & & & KPI: & \\
\hline \multirow[t]{3}{*}{3.} & & Adaptability & 12. & & Work ethics \\
\hline & Definition: & $\begin{array}{l}\text { Learning, improving, and } \\
\text { adjusting to keep up with the } \\
\text { ever changing environment. } \\
\text { Staying current on industry } \\
\text { trends and technologies. } \\
\text { Adopting proven tools and } \\
\text { best practices. .(Hawkin, } \\
\text { 2014) }\end{array}$ & & Definition: & $\begin{array}{l}\text { a belief in the moral benefit and } \\
\text { importance of work and its } \\
\text { inherent ability to strengthen } \\
\text { character. } \\
\text { www.dictionary.com/browse/w } \\
\text { ork-ethic }\end{array}$ \\
\hline & KPI: & & & KPI: & \\
\hline \multirow[t]{2}{*}{4.} & & Flexibility & 13. & & Proficiency in computer skills \\
\hline & Definition: & $\begin{array}{l}\text { the extent to which a person } \\
\text { can cope with changes in } \\
\text { circumstances and think } \\
\text { about problems and tasks in } \\
\text { novel, creative ways. [1] This } \\
\text { trait is used when stressors } \\
\text { or unexpected events occur, } \\
\text { requiring a person to change } \\
\text { their stance, outlook, or } \\
\text { commitment. Flexible } \\
\text { personality should not be } \\
\text { confused with cognitive } \\
\text { flexibility, which is the } \\
\text { ability to switch between }\end{array}$ & & Definition: & $\begin{array}{l}\text { It means that you need to be } \\
\text { good at using a computer. You } \\
\text { can be given tasks to perform on } \\
\text { a computer and with little or no } \\
\text { help, you can quickly perform } \\
\text { the assigned task. } \\
\text { www.merriam- } \\
\text { webster.com/dictionary }\end{array}$ \\
\hline
\end{tabular}




\begin{tabular}{|c|c|c|c|c|c|}
\hline & & $\begin{array}{l}\text { two concepts, as well as } \\
\text { simultaneously think about } \\
\text { multiple concepts. } \\
\text { Researchers of cognitive } \\
\text { flexibility describe cognitive } \\
\text { flexibility as the ability to } \\
\text { switch one's thinking and } \\
\text { attention between tasks.[2] } \\
\text { Flexibility, or psychological } \\
\text { flexibility as it is sometimes } \\
\text { referred to, is the ability to } \\
\text { adapt to situational demands, } \\
\text { balance life demands, and } \\
\text { commit to behaviors. } \\
\text { https://en.wikipedia.org/wiki } \\
\text { /Flexibility }\end{array}$ & & & \\
\hline & KPI: & & & KPI: & \\
\hline \multirow[t]{3}{*}{5.} & & Collaboration & 14. & & $\begin{array}{l}\text { Fluency in second, third and } \\
\text { fourth languages }\end{array}$ \\
\hline & Definition: & $\begin{array}{l}\text { Aligning interests with } \\
\text { colleagues and partners. } \\
\text { Maintaining harmony while } \\
\text { engaging in } \\
\text { constructive } \\
\begin{array}{l}\text { Fostering a climate of } \\
\text { community }\end{array} \\
\begin{array}{l}\text { trustworthiness. and } \\
\text { others with reating } \\
\text { (Hawkin, 2014) }\end{array} \\
\end{array}$ & & Definition: & $\begin{array}{l}\text { the ability to speak easily and } \\
\text { smoothly; especially : the ability } \\
\text { to speak a foreign language } \\
\text { easily and effectively } \\
\text { www.merriam } \\
\text { webster.com/dictionary/fluency }\end{array}$ \\
\hline & KPI: & & & KPI: & \\
\hline \multirow[t]{3}{*}{6.} & & Leadership & 15. & & Dedication \\
\hline & Definition: & $\begin{array}{l}\text { In an engineering context, } \\
\text { leadership incorporates a } \\
\text { number of capabilities which } \\
\text { are critical in order to } \\
\text { function at a professional } \\
\text { level, those capabilities } \\
\text { include the ability to assess } \\
\text { risk and take initiative, the } \\
\text { willingness to make } \\
\text { decisions in the face of } \\
\text { uncertainty, a sense of } \\
\text { urgency and the will to } \\
\text { deliver on time in the face of } \\
\text { constraints or obstacles, } \\
\text { resourcefulness and } \\
\text { flexibility, trust and loyalty } \\
\text { in a team setting, and the } \\
\text { ability to relate to others } \\
\text { www.merriam } \\
\text { webster.com/dictionary/dedi } \\
\text { cation }\end{array}$ & & Definition: & $\begin{array}{l}\text { a feeling of very strong support } \\
\text { for or loyalty to someone or } \\
\text { something : the quality or state } \\
\text { of being dedicated to a person, } \\
\text { group, cause, etc. } \\
\text { www.merriam- } \\
\text { webster.com/dictionary/dedicati } \\
\text { on }\end{array}$ \\
\hline & KPI: & & & KPI: & \\
\hline \multirow[t]{2}{*}{7.} & & Self-confidence & 16. & & Punctuality \\
\hline & Definition: & $\begin{array}{r}\text { Confidence is about } \\
\text { accepting what you are and } \\
\text { believing in doing great } \\
\text { things with whatever you } \\
\text { have. Confidence makes }\end{array}$ & & Definition: & $\begin{array}{l}\text { Punctuality is the characteristic } \\
\text { of being able to complete a } \\
\text { required task or fulfill an } \\
\text { obligation before or at a } \\
\text { previously designated time.[1] }\end{array}$ \\
\hline
\end{tabular}




\begin{tabular}{|c|c|c|c|c|c|}
\hline & & $\begin{array}{r}\text { your mind creative. It opens } \\
\text { you to wild } \\
\text { imagination/dreaming that } \\
\text { drives your growth. The } \\
\text { more confident you become, } \\
\text { the clearer you think and the } \\
\text { easier you conceive ideas. } \\
\text { That automatically reflects } \\
\text { in the clarity of your } \\
\text { communication and finesse } \\
\text { of your work } \\
\text { www.merriam- } \\
\text { webster.com/dictionary/dedi } \\
\text { cation }\end{array}$ & & & $\begin{array}{l}\text { "Punctual" is often used } \\
\text { synonymously with "on time } \\
\text { www.merriam- } \\
\text { webster.com/dictionary/dedicati } \\
\text { on }\end{array}$ \\
\hline & KPI: & & & KPI: & \\
\hline \multirow[t]{3}{*}{8.} & & Honesty & 17 & & $\begin{array}{l}\text { Problem solving and critical } \\
\text { thinking }\end{array}$ \\
\hline & Definition: & $\begin{array}{l}\text { As an engineer you are } \\
\text { likely to be working for the } \\
\text { benefit of a number of } \\
\text { different groups of people, } \\
\text { and in many cases you will } \\
\text { have a duty to keep these } \\
\text { people informed of relevant } \\
\text { facts. The public trusts } \\
\text { professionals to provide } \\
\text { information that is as } \\
\text { complete and accurate as } \\
\text { possible. } \\
\text { www.merriam- } \\
\text { webster.com/dictionary }\end{array}$ & & Definition: & $\begin{array}{l}\text { Using a blend of common sense } \\
\text { and analytical reasoning } \\
\text { abilities to accurately frame } \\
\text { problems, uncover their root } \\
\text { causes, evaluate alternatives, } \\
\text { and make great decisions on } \\
\text { which alternative to } \\
\text { implement.(Hawkin, 2014) }\end{array}$ \\
\hline & KPI: & & & KPI: & \\
\hline \multirow[t]{3}{*}{9.} & & Self-motivation & 18 & & Courtesy \\
\hline & Definition: & $\begin{array}{l}\text { Ability to do what needs to } \\
\text { be done, without influence } \\
\text { from other people or } \\
\text { situations. People with self - } \\
\text { motivation can find a reason } \\
\text { and strength to complete a } \\
\text { task, even when challenging, } \\
\text { without giving up or needing } \\
\text { another to encourage them. } \\
\text { www.merriam- } \\
\text { webster.com/dictionary }\end{array}$ & & Definition: & $\begin{array}{l}\text { Courtesy is all about using your } \\
\text { good manners, which is why it } \\
\text { shares roots with the word } \\
\text { courteous. Holding the door } \\
\text { open for someone, writing a } \\
\text { thank-you note for a gift, and } \\
\text { letting the pregnant lady have } \\
\text { the last seat on the bus are all } \\
\text { courtesies that would make your } \\
\text { parents proud. And if something } \\
\text { is kindly presented to you free } \\
\text { of charge, the gift-giver may say } \\
\text { it's "courtesy of" someone } \\
\text { special. } \\
\text { www.merriam- } \\
\text { webster.com/dictionary }\end{array}$ \\
\hline & KPI: & & & KPI: & \\
\hline
\end{tabular}


Appendix (2) The respondents to the interview, their names, field of study and experience

\begin{tabular}{rr|r|r}
\hline No \# & Name & Field of study & Experience/years \\
\hline 1 & Abdullah Alamoudi & Electrical Engineering & 20 \\
\hline 2 & Alhussain Ibrahim & Industrial Engineering & 10 \\
\hline 3 & Khaled Alraiqi & Mechanical Engineering & 7 \\
\hline 4 & Ahmmed Al Shlal & Mechanical Engineering & 5 \\
\hline 5 & Muhanned & Industrial Engineering & 10 \\
& Abdullah & & 10 \\
\hline 6 & Suhail Bmualim & Mechanical Engineering & 15 \\
\hline 7 & Muhammad & Industrial Engineering & 10 \\
\hline 8 & Abdullah Alaber & Electrical Engineering & 15 \\
\hline 9 & Ayman Indjane & Electrical Engineering & 20 \\
\hline 10 & Abu Ahmed & Electrical Engineering & 10 \\
\hline 11 & Salem Alghani & Electrical Engineering & 7 \\
\hline 12 & Saeed Aloberi & Mechanical Engineering & 15 \\
\hline 13 & Khaleel Odeh & Industrial Engineering & 12 \\
\hline 14 & Khaled Al-Smadi & Mechanical Engineering & 9 \\
\hline 15 & Mohamad Ajour & Electrical Engineering & \\
\hline
\end{tabular}

